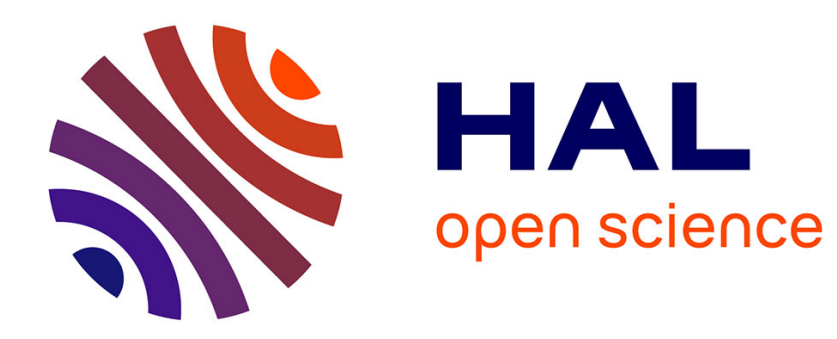

\title{
The end of organised crime in the European Union
}

Nicholas Dorn

\section{To cite this version:}

Nicholas Dorn. The end of organised crime in the European Union. Crime, Law and Social Change, 2008, 51 (2), pp.283-295. 10.1007/s10611-008-9156-y . hal-00478396

\section{HAL Id: hal-00478396 https://hal.science/hal-00478396}

Submitted on 30 Apr 2010

HAL is a multi-disciplinary open access archive for the deposit and dissemination of scientific research documents, whether they are published or not. The documents may come from teaching and research institutions in France or abroad, or from public or private research centers.
L'archive ouverte pluridisciplinaire HAL, est destinée au dépôt et à la diffusion de documents scientifiques de niveau recherche, publiés ou non, émanant des établissements d'enseignement et de recherche français ou étrangers, des laboratoires publics ou privés. 


\title{
The end of organised crime in the European Union
}

\author{
Nicholas Dorn
}

Published online: 16 October 2008

(C) Springer Science + Business Media B.V. 2008

\begin{abstract}
So much has been written - and vigorously contested - about 'organised crime' (OC) that the impending fall of this familiar icon may come as a shock, both to its detractors and to those who take it for granted. Yet that moment may be upon us, for reasons that this paper will explore, as the European Union shifts the vocabulary within which policies on police cooperation are articulated. A pivot of this change is the EU Council Decision on Europol, first debated by the Council in late 2006 and anticipated as applying from 2010 onwards. This will shift the scope of Europol's work from 'organised crime' (attributing qualities to criminality) to 'serious crime' (concern with impacts and harms falling on individual and collective victims); will transfer financing of Europol to the Community budget; and so will initiate parliamentary scrutiny. These issues in security governance are explored from 'northern', 'southern' and 'eastern' European perspectives and in the contexts of ongoing enlargement and democratisation of the EU.
\end{abstract}

\section{The Europol decision and its political context}

The political context of the EU's Council Decision on Europol [8] is the attempt of the EU to evolve from an entity with multiple legal personalities - the European Community (first pillar, focusing on the economy and trade) being distinct from the European Union (second and third pillar, foreign policy and justice and home affairs)to a unified EU, as foreseen by the Reform Treaty [4]. The Reform Treaty itself crashlanded in mid 2008 as result of the Irish 'no', following the failure of its predecessor, the Constitutional Treaty, however some of the structural changes signalled by those

\footnotetext{
N. Dorn $(\bowtie)$

Criminology Department, School of Law, Erasmus University Rotterdam,

Rotterdam, The Netherlands

e-mail: dorn@law.eur.nl

N. Dorn

Cardiff University, Cardiff, UK
} 
two treaties survive in more specific legislation. For example, the Reform Treaty would have amplified the role of the European Parliament, providing the beginnings of oversight and accountability in European police and judicial cooperation. This broad development may not now occur on a broad front-however, in relation to Europol specifically, something similar is provided for by the Europol Decision, the focus for our discussion here. In other respects, the Europol Decision goes beyond the Reform and Constitutional treaties, since it virtually does away with the problematic and controversial policing category of 'organised crime'. These are significant developments, reminding us that the political declarations that are most widely trumpeted and most hotly debated are not the only ones worth attention.

Debated within specialised European policing and political circles from the early 2000s, the Europol Decision was formally proposed by the European Commission in 2006 [8], with agreement being reached between Council and the Parliament in 2007 and 2008, and adoption scheduled for Council in October 2008. The Decision bypasses (rather than amends) the existing Europol Convention (see below), the motivation for this being to facilitate the process of agreeing and bringing into effect any and all future modifications of the legal basis for Europol and its activities, in response to emerging circumstances and changing policy priorities. By amending a Council Decision, the competencies of Europol could in future be changed within months, in contrast to the years or even decades required get ratification of changes to a Convention. In this sense, the Decision is enabling and 'flexibilising' legislation.

The Decision also moves financing of Europol from the Member States to the EU main budget (from January 2010). This will give the European Parliament a general role in oversight, since as part of the EU budgetary authority the Parliament would have some powers of check and scrutiny and, in the last instance, could block all or (more likely) part of Europol's budget. Thus the Europol Decision will introduce a minimal level of accountability of Europol at European level although - as the European Parliament has put it — further 'improvements are needed as regards Europol's democratic responsibility, especially following the extension of its operational powers' [12].

Also-the main focus for exploration in this paper-the Europol Decision shifts the focus of European police cooperation through Europol from 'organised' to 'serious' crime. In the longer term, this opens up the possibility of Europol priorities being defined in terms of the seriousness of the harms impacting on individual, collective or corporate victims.

The Europol Decision is significant for policing studies for several reasons. The change from a language of 'organised crime' to 'serious crime' underlines the importance of understanding crime policy concepts as constructed [6]. It begins to turn the page on a historical chapter that has been controversial-mafia, foreigners, OC, transnational organised crime (TOC), and so on [35]. The 'serious crime' language of the Decision resonates with an important theme in contemporary criminology: harm (see for example [22]). It also provides a fresh opening for debates on police accountability and on 'pluralistic', 'multilateral' and 'anchored' forms of security governance [18, 32, 27].

These are strongly disputed matters, and views will differ on how to evaluate the changes occurring at European level. On the one hand, some may fear further expansion of European policing. There will be easier European cooperation in 
criminal intelligence, it no longer having to be shown before opening a Europol file that the alleged criminality is 'organised' (a real impediment to cooperation in practice, as will be noted below). On the other hand, many criminologists, lawyers and human rights advocates will favour the move away from mafia models and 'othering', towards the possibility of assessments of social harm as guiding criteria for police prioritisation and cooperation.

Taking the Europol Decision in the context of the dyspeptic European debate on the Reform Treaty, we may suggest that the break-out from technical debate over what counts as 'organised' crime, the increased involvement of the European Parliament, and the prospect of an eventual merging of first and third EU pillars, may together be seen as a regional 'marker' of a global debate on security governance. 'Police cooperation' no longer refers only to cooperation within the sphere of public policing; it widens to include forms of multilateral or plural policing in which the private sector and civil society (via greater parliamentary oversight) are taken as partners by the public police. This may provoke both those strongly in favour of such developments [32] and those who emphasise the value of the public police as an 'anchor' [27] to more closely link their UK, American, African and Asian reference points to current developments in the EU.

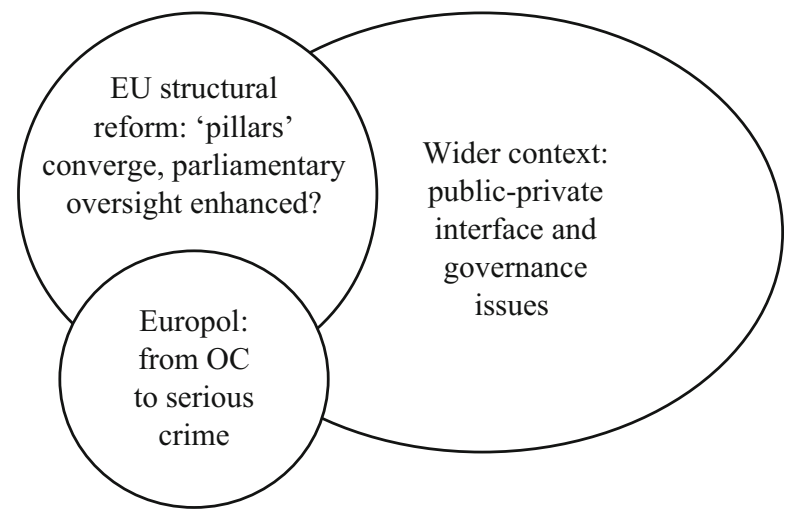

The passage of the Europol Decision also raises intriguing questions about the tension between (i) the development of a harms-based approach to policing and (ii) the concerns about 'criminal organisation' that have been re-ignited - and yet put in question - by terrorism. Terrorism is seen as more serious than OC, in respect of the political, reputational, human and other forms of damage caused. Is that because terrorism is more 'organised'? - no it is not. Following events including the bombing of London's transport system by an amateur team of young people, any presumption that seriousness of consequences necessarily ties in with sophistication of organisation would be seen as untenable. The presumed link between criminal organisation and seriousness has been broken. Criminal organisation remains of considerable and entirely legitimate concern at an enforcement operational level (since it depends what policing methods are to be employed). At policy level, 
however, a managerialist approach holds sway, within which categories of crime are prioritised for action (how intensively to police) on the basic of attributions of seriousness. This distinction has reached Europol's door.

\section{Sovereigntist ambivalence}

By way of background, of course Europol already exists: it is the EU's criminal intelligence agency. What the 2006 'Proposal for a Council Decision establishing the European Police Office' produces is a change of legal basis. Europol's present existence and competences are underpinned by a Convention [13]. The main problem the EU has experienced with this legal basis has been the difficulty of making changes, for example to enable Europol to assist Member States' national police agencies in relation to forms of criminality that were either new (e.g. cybercrime) or were unnoticed or of lesser priority in preceding years (e.g. environmental crime). As the impact assessment on the Commission's 2006 proposal puts it, there are

'clear difficulties which are currently experienced with the procedures for amendment of the Europol Convention. A dynamic and effective European law enforcement organisation can not function to the best of its capacities if changes to its main legal instrument can only enter into force 4 or 5 years after they have been decided at the highest political level'. [9]

A UK House of Commons committee responsible for scrutinising EU legislative proposals supported change, saying

'We recognised that EUROPOL can make a useful contribution to the prevention and detection of serious cross-border organised crime. We also recognised that circumstances can change quickly and that it is desirable that EUROPOL should be able to respond to change without avoidable delay. We had no difficulty, therefore, in accepting the case for replacing the EUROPOL Convention by a Decision made under the EU Treaty'. (Capitalisation as in original) [25]

The Europol Decision contains provisions to shift the financing of Europol from member state contributions to the European Community budget. This will have the effect of making Europol financially answerable to the European Parliament, to the satisfaction of the latter [12], which has been demanding an 'improvement of parliamentary scrutiny' for some time [11]). In these terms, the Council Decision represents modest but discernable movement along the accountability road, seemingly not acknowledged by some commentators (for example, Peers speaks of 'no enhancement of supervision by the European Parliament'[29]). The positive movement would be further enhanced by the EU Reform Treaty, if agreed, since this would add a power for national parliaments to scrutinise future legislation on justice and home affairs, including future modifications of or additions to the Europol Decision.

It is in this context that one may assess the change in Europol's sphere of competence, from those crimes which are 'organised', to a wider set of criminal acts that are considered to be 'serious' even if they do not meet criteria for 'OC'. In the first instance, a set of 'serious' crimes is represented by a list annexed to the 
Decision, ${ }^{1}$ a list that in future could be amended by further decisions of the Council. Central to our present purposes:

'The proposal extends the mandate of Europol to criminality which is not strictly related to organised crime. This will ease support provided by Europol to Member States in relation to cross-border criminal investigations where involvement of organised crime is not demonstrated from the start [...] One of these improvements is to ensure that Europol can assist the competent authorities of the Member States in combating specific forms of serious crime, without the current limitation that there must be factual indications that an organised criminal structure is involved. [...] [Thus] Article 4. Competence. 1. The competence of Europol shall cover serious crime affecting two or more Member States, in particular organised crime and terrorism' [4].

Council agreement on the proposal now does away with 'the current limitation that ... an organised criminal structure is involved' [4]. 'Organised' crime that is also 'serious' would continue to fall within Europol's remit; however the removal of any need to show that it is 'organised' can be expected to change police vocabulary as well as cooperation practices. Reading though the documents, there is a preponderance of references to 'serious' crime (including a few variants such as 'serious offences', 'serious crime and terrorism', and 'serious forms of international crime'). There are fewer references to 'organised' crime - most of which clearly are not advocating the concept but are referring to its limitations, from the perspective of the authors of the document (see above quote).

This is by no means the first time that such a proposal has been put on the table. In 2002, Denmark proposed that Europol should be allowed to assist in cases of 'serious international crime when two or more Member States are affected in such a way as to require a common approach by the Member States owing to the scale, significance and consequences of the offences concerned' [2]. That proposal would have removed the condition that an 'organised criminal structure' be involved, so for example it would have allowed Europol to assist in cases of lone fraudsters or killers. However, by the time the proposal was agreed in 2003, it had reverted to the following hybrid: 'serious international crime where there are factual indications or

\footnotetext{
${ }^{1}$ The list of crimes referred to by the Europol Decision (pp 52-53) is as follows: participation in a criminal organisation, terrorism, trafficking in human beings, sexual exploitation of children and child pornography, illicit trafficking in narcotic drugs and psychotropic substances, illicit trafficking in weapons, munitions and explosives, corruption, fraud, including that affecting the financial interests of the European Communities within the meaning of the Convention of 26 July 1995 on the protection of the European Communities' financial interests, laundering of the proceeds of crime, counterfeiting currency, including of the Euro, computer-related crime, environmental crime, including illicit trafficking in endangered animal species and in endangered plant species and varieties, facilitation of unauthorised entry and residence, murder, grievous bodily injury, illicit trade in human organs and tissue, kidnapping, illegal restraint and hostage-taking, racism and xenophobia, organised or armed robbery, illicit trafficking in cultural goods, including antiques and works of art, swindling, racketeering and extortion, counterfeiting and piracy of products, forgery of administrative documents and trafficking therein, forgery of means of payment, illicit trafficking in hormonal substances and other growth promoters, illicit trafficking in nuclear or radioactive materials, trafficking in stolen vehicles, rape, arson, crimes within the jurisdiction of the International Criminal Court, unlawful seizure of aircraft/ships, sabotage.
} 
reasonable grounds for believing that an organised criminal structure is involved and two or more Member States are affected in such a way as to require a common approach by the Member States owing to the scale, significance and consequences of the offences concerned' [3]. In other words, OC had been re-instated. A similar and previous proposal of Sweden and Belgium was rejected by the European Parliament on the basis that, whilst a move from 'organised' to 'serious' crime was acceptable, the manner in which the proposal was framed would have perpetuated a purely intergovernmental approach to European policing and would not have been a step in the direction of accountability to the Parliament [11, 24]. Thus the question of the widening of Europol's roles and tasks and the question of its accountability have been linked points of struggle for some years.

As of 2007, political (and as we will indicate below academic) debate remained. On the organised/serious question, a European Council Europol Working Party noted that 'Some delegations underlined that Europol should focus on combating organised crime' [16]. This remaining attachment to OC stems from several quite distinct sources. The first is the well-known attachment of some EU member states to the maintenance of sovereignty in the area of justice, freedom and security, an attachment causing the UK and some others to vacillate over or even block otherwise acceptable initiatives, for fear that they may widen EU competences. This attachment motivated one of the UK's 'red lines' on the Reform Treaty, resulting in agreement over an 'opt out' provision for the UK on EU justice and police matters. The UK has been to the fore in pressing for pragmatic solutions to police cooperation, exchange of data in line with 'the principle of availability', and tasking of enforcement agencies according to criteria of the harm caused by crime. The harm approach first became explicit in domestic policing in the UK in relation to drug use, possession and trafficking ('the drugs that do the most harm'). Harm then became quite a generalised principle in UK policing [33], even if the title of the Serious Organised Crime Agency (SOCA) 'hedges its bets' over the referents 'organised' and 'serious' crime. But, despite the commitment at national level to using concepts of harm to steer priority-setting (or at least to develop and modify concepts of harm so that they are compatible with politically acceptable enforcement priorities) - and in spite of sighs of impatience within the UK enforcement community with 'southern' commitment to language and concepts of mafia and OC-still the UK suffered 'cold feet' in arguing the case for serious crime at European level. This is simply because OC, as a more restricted concept than serious crime, provides a more limited definition of boundaries of Europol competence, and so is more compatible with sovereigntist concerns. Hence, in 2007,

'The Minister of State at the Home Office (Mr Tony McNulty) told us that the Government supports the proposal to replace the EUROPOL Convention by a Decision under the EU Treaty. [...] But the Government had reservations about some of the provisions of the draft Decision. The Minister said that the Government would, for example, consider whether there might be circumstances to justify the involvement of EUROPOL in crime that is serious but which is not strictly "organised crime"; but it would be very cautious about an enlargement of EUROPOL's remit that would divert it from its principal focus on the analysis of criminal intelligence' [25]. 
Why this caution? The historical record suggests that the British government is not so much worried about an expansion of police cooperation per se. Rather, the government is concerned not to give the political opposition an opportunity to attack it for 'selling our sovereignty down the river'. Indeed, the government took quite a risk by not opposing the proposal contained in the Decision for funding of Europol to be borne by the EU core budget, with the implication of some degree of accountability to the European Parliament. The House of Commons European Scrutiny Committee [26] was told by the Home Office Minister 'that the Government would prefer EUROPOL to remain funded directly by the Member States. It could accept the change to Community funding only if it did not increase expenditure'. Thus the UK quietly accepted the principle of funding of Europol through the EU budget, and the modest beginnings of police accountability through the European Parliament, in spite of the danger of a sovereigntist backlash.

Another aspect of UK concern related to the practicality of proposals. The House of Commons Home Affairs Committee put this concern in the following manner.

'Policing co-operation across the EU. [... 6. We believe that the creation of Europol has been a positive development in facilitating police co-operation, particularly by building confidence and knowledge between Member States. [But] We do not believe Europol has yet achieved its full potential [...] its work appears to be hampered by the varying degrees of co-operation it receives from other Member States. [Thus] 7. The Commission's recent proposal further to extend the powers of Europol will require careful examination by the UK Government. In the light of the evidence we have received from UK police, it does not appear to us that there is a pressing need for a further extension of powers [...]' [26].

If we read this in combination with the previously mentioned worries over sovereignty, then we may discern a disinclination amongst MPs, and of the police representatives who briefed them, to extend the boundaries of an EU agency whose levels of functioning and governance fall short of optimal. On balance, however, the shift from 'organised' to 'serious' crime, and the balancing of inter-governmental tasking of Europol by modest oversight by the European Parliament, were seen as being practical, desirable and achievable.

\section{'Serious' and 'organised' in relation to state capture and elite crime}

Turning briefly to some southern EU member states, political concerns differ somewhat. There seems to be less political ('sceptical' or sovereigntist) concern over the third pillar of the EU, indeed over the EU generally. On those grounds alone, European Parliamentary oversight would be unproblematic.

However, the re-casting of Europol interests from 'organised' to 'serious' crime is quite another matter, because of cultural and historical attachments to concepts and language of OC, mafia and so on. For example, Italian post-war history, policy, media and indeed criminology indicates a depth of popular as well as political engagement with the idea of crime being 'organised'. Such commitments extend into the European research community and there have been valiant attempts to maintain, 
rehabilitate, make 'scientific' and render quantifiable the category of $\mathrm{OC}$, in order to support its continuing use as the framing concept for European police prioritysetting, management and reporting [30], attempts that have been criticised by some [34]. Such specific definitional difficulties add to institutional difficulties observed in police reporting in practice (see for example [31].

The debate on how to characterise Euro-crime is by no means only between 'north' and 'south'. There is also a strong 'eastern' dimension, which has a discomforting tie-in with the evolution of the European Union. Aleksandar Fatic paints a picture of crime in the Balkans that is (i) serious, (ii) organised and (iii), it is alleged, tolerated by the EU, as part of the price to be paid for the political journey of the Balkans from 'east' to 'west'.

'In Montenegro, the government of Prime Minister Milo Đukanović was forced to resort to cigarette-smuggling rings for support in order to finance the state budget and the loyal party elite necessary to maintain a hold on power, while in Serbia organised crime was more 'classic' in shape and reminiscent of the criminal rings that operated in the US during the prohibition or in Europe in the 1960s. In Albania, the general poverty and cultural stereotypes allowed for the development of human trafficking, and the traditional use of Kosovo as a part of the route for smuggling heroin from the middle east to western Europe accounted for the attempts by Kosovar separatists to run a developed heroin racket in order to fund terrorist actions against the Serbian security forces and, ultimately, an independence war in 1999. [...] In all these cases, criminals played a key role in reinforcing the political leaders' [17].

There is a strand in European police intelligence thinking that orientates to such questions by defining the worst crime 'threats' as being those that are most resistant to policing, because of their organisational and technical sophistication and, particularly, because of their embeddedness in political structures [14]. ${ }^{2,3}$ A statement to that effect occurred in the Europol's 2006 Organised Crime Threat Assessment, or OCTA [14]. It did not recur in the 2007 OCTA [15]. By way of context, the accession of Bulgaria and Romania to the EU took place in January

\footnotetext{
2 The 2006 Organised Crime Threat Assessment of Europol puts it this way: 'The model adopted in this threat assessments points to the types of OC groups that must be regarded as the most dangerous [...] the focus should be on OC groups displaying structural or functional qualities supporting the resistance of these groups to dismantling attempts. [...] The main threatening aspects of the groups are, first, the overwhelming obstacles in dismantling them because of their international dimension or influence, and second, their level of infiltration in society and economy'[14].

${ }^{3}$ In a similar vein, the present author recalls a discussion with a senior UK police officer who, gesturing to the world outside the window, described the agency as being continuously 'under attack' (and he did not mean by civil liberty critics). The point for present purposes is that, should sophisticated crime groups succeed in seriously degrading the ability of a police agency to function, then the priorities of that agency could be regarded as somewhat moot. The survival instinct predisposes policing agencies and their ministries (where neither corrupt nor constrained by other political priorities) to attend first and foremost to those criminals and their allies having the highest ability to neutralise policing. In this perspective, considerations of other harms become secondary.
} 
2007. The situation in these countries is seen as not being satisfactory in relation to judicial reform, corruption and organised crime, nevertheless these countries were admitted to the EU, with continuing membership being made subject to 'verification' procedures [10]. This top level compromise might have contributed to the dropping of these issues in Europol's 2007 report. Ironically, we may have EU shyness over the justice and home affairs implications of enlargement to thank for a movement away from public drum-banging about 'OC'.

On reflection, neither OC nor serious crime concepts go far enough to be capable of capturing some realities: one would have to expand both concepts to take in elite crime locally and (more radically) EU accommodation regionally. However, it would not be the first time that market opening and facilitation has been rather dirty (see for example [20]). Not only in central and eastern Europe: the British Aerospace affair (see [1] and [19]) indicates another accommodation, whose negative value has yet to be fully assessed - although investigations by the US Department of Justice, the OECD [28] and even by Eurojust [7], a companion agency to Europol, may provide some yardsticks. One may wonder whether crime in which political elites are involved or complicit could ever effectively be tackled by agencies of the states concerned, acting alone, be they the Bulgarian police or the UK's Serious Fraud Office. Perhaps there are circumstances in which one should be somewhat grateful for international assistance.

In summary, whilst the cameo presentations given above of 'northern', 'southern' and 'eastern' constructions of the issues involved in understanding and defining crime seriousness may be somewhat stereotypical, they reflect culturally and politically recognisable starting points that, if brought into contact with each other, throw up serious questions about each. In UK government discourse and research, seriousness is constructed in terms of harms falling upon individuals and collective interests, translating those impacts into financial costs, then adding the general costs of prevention and the costs of responses to (known) crime events (see generally [23]; specifically on OC, [5]). Somewhat against this mainstream, there runs a critical discourse on wider harms, not all of which may be represented in criminal law or adequately policed or regulated - such as environmental spoilage, financial market manipulation, state crime and toleration of corruption.

From a 'southern' perspective arises a preoccupation with the 'organised-ness' of crime-expressed through such concepts as the international reach of criminality, its structures, use of legitimate business structures, capacity for violence, etc. [15] - the harmfulness of these organisational qualities of the phenomena culturally and historically being seen as so obviously harmful that there is no need to check upon impacts on victims.

From 'eastern' locations can be seen most clearly an interleaving of crime with elites, markets, the judiciary and police - in other words, systemic or institutional harms, about which western European countries may have cultivated a domestic blindness.

It does not follow, from the heterogeneity of these concerns, that all of them necessarily would have to be encompassed in any eventual European Union formulation of seriousness and priority-making. However it does seem both politically inevitable and potentially helpful that discussion involves their acknowledgement. 


\section{Conclusion}

This paper draws attention to the EU Europol Decision, and especially to the manner in which it changes the sphere of police cooperation through Europol, from 'organised crime' (how criminality is constituted) to 'serious crime' (who and how it harms). The Decision also provides for a role for the European Parliament, as part of the budgetary authority, in oversight of Europol. Both changes can be seen as being in line with the wider changes that would have been put in place by the EU Reform Treaty, with its merging of first and third pillars - a prospect that calls for further analysis in terms of governance of the expanding private/public policing space. An important and yet-to-be-clarified aspect of this public-private merging concerns the conditions under which Europol acquires personal data from commercial sources (everyday financial transactions, etc). ${ }^{4}$

Normatively, where could one stand in this debate? Several major problems with the concepts of OC are acknowledged: its fuzzy boundaries (how many people? over what time period? with or without threats or violence? etc!); its political partiality (tendency to focus upon foreigners and away from corporate crime); and the difficulties of reporting against it in a meaningful and consistent manner. The concept generates more heat than light. It causes difficulties for police prioritysetting, management, intelligence, reporting - and hence for the prospects for accountability. In this perspective, a movement away from $\mathrm{OC}$ has practical and political attractions.

However, it must be admitted that efforts to operationalise seriousness and harm are in their infancy. Some of the critical work that arguably is most interesting has a fine intellectual and political edge, but it is not very close to existing police, administrative or private sector information systems. By contrast, some allegedly 'scientific' approaches look so much to data availability and quality that they commit manifest absurdities - for example by including in estimates of harmfulness of offences the discretionary costs of policing them. Such an approach can only form a positive feedback loop, in which whatever has been most attended to in the past becomes assessed as most harmful and most deserving of future action. To avoid such automatism, harm measures should have nothing to do with response costs.

Undoubtedly, the technical challenges in defining harms and seriousness in a manner that is useful for prioritising and steering European policing will be found no less difficult than those of defining and estimating OC. ${ }^{5}$ The considerable advantage of a focus on harm/seriousness, however, is that it widens out the debate, from enforcement agency staff, analysts and allied researchers (practitioner-experts on the 'organised-ness' of crime groups), to wider public and civic domains (a diverse set

\footnotetext{
${ }^{4}$ As the Home Office Minster put it, possibly evading the main matter of principle involved in privatepublic data exchange: 'At present there are no formal agreements between Europol and public or private entities relating to the provision of commercial data to Europol. However, the Government's view is that where that would involve the processing of personal data from public or private entities, it must take place exclusively via the Europol national units. A new legal instrument to regulate Europol's activities [the Council Decision] is currently under negotiation in the Justice and Home Affairs Council. In the context of that negotiation, the question of the provision of commercial data to Europol has yet to be discussed.' [21]

${ }^{5}$ van Duyne, P., 2008, personal communication.
} 
of actors having a variety of interests in defining harm/seriousness). It then will fall to criminologists and others to take up the challenge of illuminating the assumptions, choice points, data pools and methodologies for unpacking seriousness in terms of harm.

In conclusion, the shift from 'organised' to 'serious' crime, as signalled by the Europol Decision, opens up possibilities for police/public/parliamentary debatepossibilities that up to now have been impeded by arcane and ethnicised debates over what constitutes 'organisedness'. The Europeanisation of financing foreseen by the Decision, and hence the beginning of accountability to the European Parliament, puts a material floor under an otherwise ungrounded governance debate. From these points of view the Europol Decision may be afforded a conditional welcome. There remains the challenge of how adequately to represent, within an over-arching concept of crime seriousness, the systemic damage done to political culture and institutions by EU and national elites' accommodations to market crimes, corruption and cover-up. This is a challenge that should be taken up internationally.

\section{References}

1. Chatham House International Law discussion group (2007). Anti-Corruption Obligations and the UK System of Prosecution: a summary of the Chatham House International Law discussion group meeting held on 30 April. London: Royal Institute of International Affairs. www.chathamhouse.org.uk/ publications/papers/download/-/id/486/file/9830 il300407.pdf. Accessed 12 September 2008.

2. Council of the European Union (2002). Initiative of the Kingdom of Denmark with a view to adopting a Council Act drawing up, on the basis of Article 43(1) of the Convention on the Establishment of a European Police Office (Europol Convention), of a Protocol amending that Convention. 10307/02, EUROPOL 46, 2 July. Brussels: Council of the European Union. http://register.consilium.eu.int/pdf/ en/02/st10/10307en2.pdf. Accessed 12 September 2008.

3. Council of the European Union (2003). Council Act drawing up, on the basis of Article 43(1) of the Convention on the establishment of a European Police Office (Europol Convention), a Protocol amending that Convention. 13650/03, EUROPOL 53. Brussels: Council of the European Union. http://www.statewatch.org/news/2007/jan/europol-third-protocol-2003.pdf. Accessed 12 September 2008.

4. Council of the European Union (2007). Brussels European Council 21/22 June 2007: Presidency Conclusions, 23 June. 11177/07, CONCL 2. Brussels: European Council. See especially Annex I: Draft IGC Mandate, p 15 onwards. http:/www.consilium.europa.eu/uedocs/cms_Data/docs/pressdata/en/ ec/94932.pdf. Accessed 12 September 2008.

5. Dubourg, R., \& Prichard, S. (2007). The impact of organised crime in the UK: revenues and economic and social costs. In Home Office (Ed.), Organised crime: revenues, economic and social costs, and criminal assets available for seizure. Home Office Online Report 14/07. London: Home Office (withdrawn summer 2007 from http://www.homeoffice.gov.uk/rds/orgcrime1.html, revised version awaited).

6. Edwards, A., \& Gill, P., Eds. (2003). Transnational Organised Crime: The Policy and Politics of Global Crime. London: Routledge.

7. Eurojust (2007). Eurojust held co-ordination meeting on JAS Gripen jetfighters case, press announcement, 10 May. The Hague: Eurojust. http://eurojust.europa.eu/press_releases/2007/10-052007.htm. Accessed 12 September 2008.

8. European Commission (2006a). Proposal for a Council Decision establishing the European Police Office (EUROPOL), presented by the Commission SEC(2006) 1682 \& SEC(2006) 1683. Brussels: European Council. http://register.consilium.europa.eu/pdf/en/07/st05/st05055.en07.pdf. Accessed 12 September 2008.

9. European Commission (2006b). Commission Staff Working Document: Accompanying document to the Proposal for a Council Decision Establishing the European Police Office (Europol): Impact Assessment, COM(2006) 817 final, SEC(2006) 1683. Brussels: European Union. http://eur-lex.europa. 
eu/smartapi/cgi/sga_doc?smartapi!celexapi!prod!CELEXnumdoc\&lg=EN\&numdoc=41995A1127(01) \&model=guichett. Accessed 12 September 2008.

10. European Commission (2007). Bulgaria and Romania make progress but much remains to be done to tackle judicial reform and corruption. IP/07/948, 27 June. Brussels: European Commission. http:// europa.eu/rapid/pressReleasesAction.do?reference $=\mathrm{IP} / 07 / 948 \&$ format $=\mathrm{PDF} \&$ aged $=0 \&$ language $=$ EN\&guiLanguage=en. Accessed 12 September 2008.

11. European Parliament (2002). Report on the initiative of the Kingdom of Belgium and the Kingdom of Spain with a view to adopting a Council Act drawing up a Protocol amending the Convention on the establishment of a European Police Office (Europol Convention. http://www.europarl.europa.eu/sides/ getDoc.do?type=REPORT\&reference=A5-2002-0173\&language=CS\&mode=XML. Accessed 12 September 2008.

12. European Parliament (2007). Working Document on the establishment of the European Police Office (Europol), Committee on Civil Liberties, Justice and Home Affairs, Rapporteur: Agustín Díaz de Mera García Consuegra. DT $\backslash 652813 E N . d o c$, PE 384.579v01-00, 19.2.2007. Brussels: EP. http://www. europarl.europa.eu/meetdocs/2004_2009/documents/dt/652/652813/652813en.pdf. Accessed 12 September 2008.

13. European Union (1995). Europol Convention: Convention based on Article K.3 of the Treaty on European Union, on the establishment of a European Police Office, Official Journal of the European Communities. C 316, 27/11/1995, 0002-0032. http://ec.europa.eu/justice_home/doc_centre/police/ europol/wai/doc_police_europol_en.htm. Accessed 12 September 2008.

14. Europol (2006). European Union Organised Crime Threat Assessment 2007. The Hague: Europol. http://www.europol.europa.eu/publications/European_Organised_Crime_Threat_Assessment (OCTA)/OCTA2006.pdf. Accessed 12 September 2008.

15. Europol (2007). European Union Organised Crime Threat Assessment 2007. The Hague: Europol. http://www.europol.europa.eu/publications/European_Organised_Crime_Threat_Assessment_ (OCTA)/OCTA2007.pdf. Accessed 12 September 2008.

16. Europol Working Party (2007). Outcome of proceedings on 18 and 19 January 2007. Europol 10. Doc 5560/07. Brussels: Council of the European Union. http://www.statewatch.org/news/2007/jan/europol5560-07.pdf. Accessed 12 September 2008.

17. Fatić, A. (2004). The criminal syndicate as para-state in the Balkans: is the 'New War-Making Criminal Entity' a reality? South-East Europe Review, 4, 137-156.

18. Fijnaut, C. (2002). Introduction to the special issue on police accountability in Europe. Policing and Society, 12(4), 243-248.

19. Financial Times (editorial comment) (2007). Department of Justice is right to investigate BAE Systems. London: Financial Times, 27 June. http://www.ft.com/cms/s/9e9a7c62-24e0-11dc-bf47000b5df10621.html. Accessed 12 September 2008.

20. Frisby, T. (1998). The Rise of Organised Crime in Russia: its Roots and Social Significance. EuropeAsia Studies, 50(1), 27-49.

21. Hiller, M. (2007). Hansard (House of Commons Daily Debates), 4 July, Column 1046W. London: House of Commons. http://www.publications.parliament.uk/pa/cm/cmhansrd.htm. Accessed 12 September 2008.

22. Hillyard, P., Pantazis, C., Tombs, S., \& Gordon, D., Eds. (2004). Beyond Criminology: Taking Harm Seriously. London: Pluto Press.

23. Home Office/ Brand, S., \& Price, R. (2000). The economic and social costs of crime, Research Study 217. London: Home Office, Economics and Resource Analysis. http:/www.homeoffice.gov.uk/rds/ pdfs/hors217.pdf. Accessed 13 September 2008.

24. House of Commons European Scrutiny Committee (2001). European Scrutiny, Third Report, Possible amendments to the Europol Convention and possible extensions of Europol's mandate. HC 152-iii. London: Her Majesty's Stationary Office. http://www.publications.parliament.uk/pa/cm200102/ cmselect/cmeuleg/152-iii/15215.htm. Accessed 12 September 2008.

25. House of Commons European Scrutiny Committee (2007). Seventeenth Report of Session 2006-07. Documents considered by the Committee on 18 April. HC 41-xvii, London: The Stationery Office Limited. http://www.publications.parliament.uk/pa/cm200607/cmselect/cmeuleg/41-xxi/4106.htm. Accessed 12 September 2008.

26. House of Commons Home Affairs Select Committee (2007). Third Report, Justice and Home Affairs Issues at European Union Level. HC 76-I, 5 June. London: The Stationery Office Limited. http:// www.publications.parliament.uk/pa/cm200607/cmselect/cmhaff/76/76i.pdf. Accessed 12 September 2008. 
27. Loader, I., \& Walker, N. (2006). Necessary virtue: the legitimate place of the State in the production of security. In J. Wood, \& B. Dupont (Eds.), Democracy, Society and the Governance of Security (pp. 165-195). Cambridge: CUP.

28. Organisation for Economic Cooperation and Development (2007). L'OCDE va procéder à un nouvel examen des efforts de lutte contre la corruption du Royaume-Uni (OECD to conduct a further examination of UK efforts against bribery), Paris: OECD. http://www.oecd.org/document/51/0,3343, en_2649_201185_38253619_1_1_1_1,00.html. Accessed 12 September 2008.

29. Peers, S. (2007). Europol: The final step in the creation of an "Investigative and Operational" European Police Force. Statewatch analysis. London: Statewatch. http:/www.statewatch.org/news/ 2007/jan/europol-analysis.pdf. Accessed 12 September 2008.

30. Savona, E. et al. (2008). IKOC, Improving Knowledge on Organised Crime to develop a common European approach, Rotterdam: Erasmus University Rotterdam, ISBN number 978-90-79757-01-5 (in press).

31. Sheptycki, J. (2004). Organizational Pathologies in Police Intelligence Systems: Some Contributions to the Lexicon of Intelligence-led Policing. European Journal of Criminology, 1(3), 307-332.

32. Shearing, C. (2006). Reflections on the refusal to acknowledge private governments. In J. Wood, \& B. Dupont (Eds.), Democracy, Society and the Governance of Security (pp. 10-32). Cambridge: CUP.

33. Serious Organised Crime Agency (2005). Management Statement for the Serious Organised Crime Agency. London: SOCA. http://www.soca.gov.uk/downloads/Management_Statement_\&Financial_ Memorandum_2005.pdf. Accessed 12 September 2008.

34. Van Duyne, P., Maljevic, A., van Dijck, M., von Lampe, K., \& Newell, J. (2006). The organisation of crime for profit: conduct, law and measurement. Nijmegen: Wolf.

35. Woodiwiss, M. (2003). Transnational Organised Crime: the Global Reach of an American Concept. In A., Edwards, \& P. Gill (Eds.),Transnational Organised Crime: The Policy and Politics of Global Crime. London: Routledge. 